G.E. Townsend MD FRCP(C), J.E. Wynands MD FRCP(C), D.G. Whalley MB FFARCS FRCP(C), P. Wong B SC, D.R. Bevan MB MRCP FFARCS

\title{
Role of renin- angiotensin system in cardiopulmonary bypass hypertension
}

The role of the renin-angiotensin system in the aetiology of perioperative hyperiension was studied in 15 previousty normotensive patients undergoing coronary artery surgery and anaesthetized with fentanyl. Measure. ments of plasma renin activity were made at intervals before and during cardiopulmonary bypass (CPB). In addition, angiotensin II blockade with saralasin was used in an attempt to treat hypertensian during CPB.

Nine of the patients became hypertensive (increase in systemic pressure of more than 20 per cen') before $C P B$ and although the mean plasma renin activity was higher in this group than in the normotensive patients it was within normal limits for each group. Hypertension during $C P B$ (mean blood pressure greater than $100 \mathrm{mmHg}$ at $1.81 \cdot \mathrm{m}^{-2}$ fow), occurred in seven patients but was not associated with increased renin activity and did not respond to saraiasin in doses up to $20 \mu \mathrm{\mu g} \cdot \mathrm{kg}^{-1} \cdot \mathrm{min}^{-1}$. It is conciuded that cardiopulmonary bypass associated hypertension is not mediated by activation of the reninangiotensin system.

Key words

ANAESTHESIA: Cardiac; HYPERTENSION: cardiopulmonary bypass, renin-angiotensin, saralasin.

From the Department of Anaesthesia, Royal Victoria Hospital \& McGill University, Montreal, Quebec.

Address correspondence to: Dr. G.E. Townsend, Department of Anaesthesia, Royal Victoria Hospital, 687 Pine Avenue West, Montreal, Quebec, H3A 1Al.

Supported by Medical Research Council of Canada Student Grant and Norwich Eaton Laboratories.
The aetiology of the hypertension which develops during cardiopulmonary bypass (CPB) is uncertain. It has been attributed to the release of catecholamines but changes in blood pressure (BP) do not correlate with circulating concentrations of epinephrine and norepinephrine. ${ }^{1}$ The role of other pressor hormones such as vasopressin ${ }^{2}$ and angiotensin $1 \mathrm{I}^{3,4}$ has also been suggested but not proved.

The present study was designed to determine whether activation of the renin-angiotensin system correlated with BP increases before and during CPB. Blood was collected intermittently throughout surgery for estimation of plasma renin activity (PRA) which was correlated with elevation of systolic blood pressure. In addition, attempts were made to reduce hypertension during $\mathrm{CPB}$ with infusion of the angiotensin II antagonist, saralasin.

\section{Methods}

The protocol was approved by the Hospital Ethics Committee. After informed consent, 15 patients undergoing $\mathrm{CPB}$ for coronary artery disease were studied. Before operation, they were normotensive, BP of 160/100 or less and free of renal dysfunction as determined by normal serum creatinine and blood urea concentrations. Preoperative angiography demonstrated severe $(>50$ per cent) obstruction of the left main coronary artery in al patients and most had multiple vessel disease. Medications (Table I), were continued up to the night before surgery except for propranalol which was also given on the morning of operation. Premedication consisted of flurazepam, $30 \mathrm{mg}$, as night sedation and diazepam $0.15 \mathrm{mg} \cdot \mathrm{kg}^{-1}$ orally, morphine $0.15 \mathrm{mg} \cdot \mathrm{kg}^{-1}$ IM and scopolamine, $0.4 \mathrm{mg} \mathrm{IM}, 60$ to 90 minutes before surgery.

On arrival in the operating room, an electrocardiogram was attached to the patient and a modified V5 lead was monitored throughout surgery. Cathe- 
TABLE I Demographic data (Mcan \pm SEM)

\begin{tabular}{|c|c|c|c|c|}
\hline & \multicolumn{2}{|l|}{ Pre bypass } & \multicolumn{2}{|l|}{ During bypass } \\
\hline & Hypertensive & Normotensive & Hypertensive & Normotensive \\
\hline$\pi$ & 9 & 6 & 7 & 8 \\
\hline Age (yr) & $55.1 \pm 3.6$ & $55.5 \pm 4.6$ & $52.7 \pm 3.9$ & $57.5 \pm 3.8$ \\
\hline $\mathrm{Ht}(\mathrm{cm})$ & $175 \pm 1.7$ & $163.4 \pm 4.0$ & $171 \pm 1.9$ & $169.2 \pm 4.3$ \\
\hline$W(\mathrm{~kg})$ & $77.3 \pm 4.0$ & $64.5 \pm 4.4$ & $74.1 \pm 2.9$ & $70.5 \pm 5.9$ \\
\hline $\operatorname{BSA}\left(\mathrm{m}^{2}\right)$ & $1.92 \pm 0.04$ & $1.7 \pm 0.07$ & $1.86 \pm 0.03$ & $1.79 \pm 0.08$ \\
\hline Sex & $9 \mathrm{M}$ & $4 \mathrm{M}, 2 \mathrm{~F}$ & $7 \mathrm{M}$ & $6 \mathrm{M}, 2 \mathrm{~F}$ \\
\hline Grafts (n) & $2.8 \pm 0.3$ & $2.7 \pm 0.6$ & $3.4 \pm 0.3$ & $2.9 \pm 0.7$ \\
\hline \multicolumn{5}{|l|}{ Medication: } \\
\hline Nitrates & $8 / 9$ & $6 / 6$ & $6 / 7$ & $8 / 8$ \\
\hline B block & $8 / 9$ & $6 / 6$ & $7 / 7$ & $8 / 8$ \\
\hline Diuretics & $1 / 9$ & 116 & $1 / 7$ & $1 / 8$ \\
\hline
\end{tabular}

ters for haemodynamic measurements were inserted under local anaesthesia. An arterial line was positioned in a radial artery and a Swan Ganz thermodilution catheter in the pulmonary artery. These enabled measurements to be made of left and right heart filling pressures, systemic and pulmonary arterial pressures, and cardiac output.

All patients were anaesthetized with fentanyl which was given in a dose of $75-150 \mu \mathrm{g} \cdot \mathrm{kg}^{-1}$. After induction of anaesthesia the patients received pancuronium to a total of $0.15 \mathrm{mg} \cdot \mathrm{kg}^{-1}$, werc intubated and ventilated with 100 per cent oxygen to maintain normocarbia.

Intravascular volume was maintained by infusion of crystalloid and blood to keep pulmonary artery diastolic pressure at $10-15 \mathrm{mmHg}$. Total crystalloid infused varied between $2650-7550 \mathrm{ml}$ which included $1750 \mathrm{ml}$ of bypass priming fluid. Systolic and pulmonary blood pressures and EKG were recorded continuously. During non-pulsatile $\mathrm{CPB}$ the flow was maintained at $2.41 \cdot \mathrm{m}^{-2}$ at notmothermia and $1.81 \cdot \mathrm{m}^{-2}$ when the temperature was decreased to $26-28^{\circ} \mathrm{C}$. Normothermia was restored at the end of CPB. The heart was protected with cardioplegic solution (Ringer's lactate, $500 \mathrm{ml}$, $10 \mathrm{meq} \mathrm{KCl}, 12.5 \mathrm{ml}$ lidocaine two per cent, 12.5 meq $\mathrm{NaHCO}_{3}, 17 \mathrm{ml} 50$ per cent dextrose at less than $5^{\circ} \mathrm{C}$ ) during $\mathrm{CPB}$.

Control haemodynamic data were recorded after insertion of cannulae before induction of anaesthesia and were repeated at the following times; after induction of anaesthesia, skin incision, stemotomy and aortic dissection. Mean blood pressure $(\overline{\mathrm{BP}})$ was recorded 10 minutes after starting $\mathrm{CPB}$ and at 30-minute intervals. Blood was taken for estimation of PRA, before operation and also at the same times as the recording of haemodynamic data. Renin activity was estimated by a modification of the method described by Haber et al. ${ }^{5}$ using New England Nuclear reagents. Plasma was incubated for two hours to generate angiotensin I which was estimated by radioimmunoassay and the plasma renin activity was reported as $\mathrm{ng} \cdot \mathrm{ml}^{-1} \cdot \mathrm{hr}^{-1}$ of angiotensin I generated.

Hypertension occurring before CPB was defined as an increase in systolic blood pressure of more than 20 per cent of the pre-anaesthetic control value. During CPB it was defined as a mean $B P$ greater than $100 \mathrm{mmHg}$ at a flow of $1.81 \cdot \mathrm{m}^{-2}$. It was treated before $\mathrm{CPB}$ with addition of an inhalational anaesthetic agent, halothane or enflurane, which was discontinued at the start of CPB. During $C P B$ initial treatment of hypertension was attempted with saralasin administered in an initial dose of $7.5 \mu \mathrm{g} \cdot \mathrm{kg}^{-1} \cdot \mathrm{min}^{-1}$ and, if ineffective, increased incrementally to $10,12.5,15$ and $20 \mu \mathrm{g}$. $\mathrm{kg}^{11} \cdot \mathrm{min}^{-1}$ at three-minute intervals.

The data are presented as mean values \pm SEM Student's $t$ test was applied where indicated, paired (STp) for within group and unpaired (STu) for between group comparisons. Bonferroni's modification was used for multiple comparisons and the null hypothesis was rejected when $p<0.05$. Regression lines were constructed by the least squares regression method and correlation coefficients calculated where necessary. 


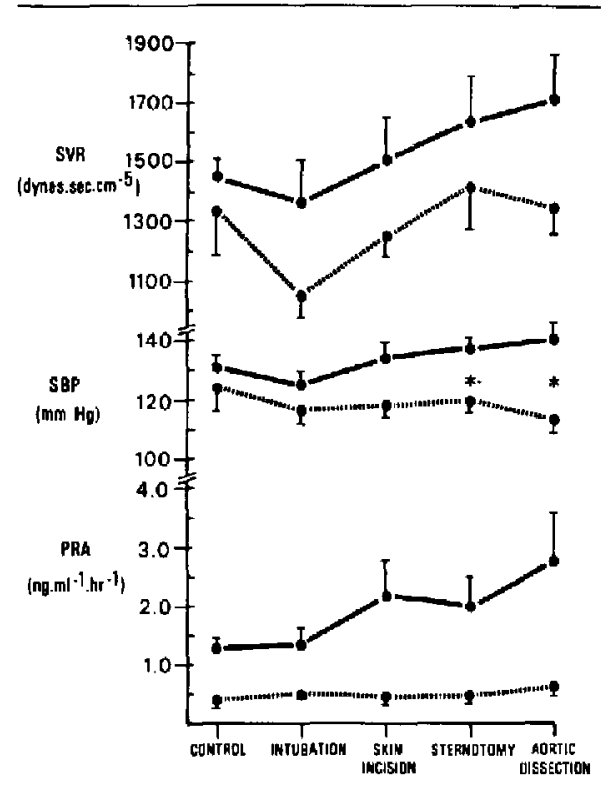

FIGURE 1 Mean changes in systemic vascular resistance (SVR), systolic blood pressure (BP) and plasma renin activily (PRA) at specific times before cardiopulmonary bypass.

The solid line represents thosc patients who became hypcrtensive and the dotted tine those who did not. $\left({ }^{*} p<0.05\right)$.

\section{Results}

The demographic data are shown in Table I with the patients divided according to the presence or absence of hypertension before and during CPB. The hypertensive and normotensive groups were similar in their preoperative medication regimens and physical characteristics except that neither of the two women became hypertensive.

Before CPB, increases of systemic vascular resistance (SVR) and $\mathbf{B P}$ occurred in 9 patients who were then given additional volatile anaesthetic. Significant differences in BP were demonstrated between those patients who became hypertensive and those who did not only at sternotomy and aortic dissection (STu). Failure to demonstrate further statistical differences either within (STp) or between (STu) these two groups was mainly because of the treatment imposed when the BP exceeded predetcrmined limits. Plasma renin activity remained within the normal range $\left(0.5-3.8 \mathrm{ng} \cdot \mathrm{ml}^{-1}\right.$

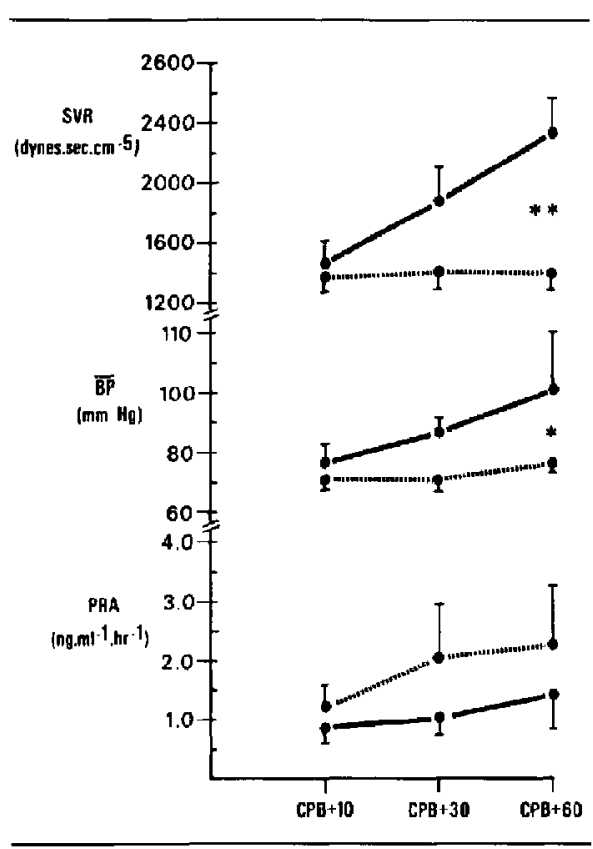

FIGURE 2 Mean haemođynamic responses and plasma renin activity during cardiopulmonary bypass in those paticnts who became hypertensive (solid line) or remained normotensive (dotted line). ( ${ }^{*} p<0.05 ;{ }^{* *} p<0.01$ ).

$\mathrm{hr}^{-1}$ ) and was not statistically different between the two groups (STu) at any time (Figure I).

During $\mathrm{CPB}, \overline{\mathrm{BP}}$ and $\mathrm{SVR}$ increased in seven of the 15 patients, four of whom had developed pre-CPB hypertension (Figure 2). Mean BP exceeded $100 \mathrm{mmHg}$ at a mean time of $57.3 \pm 5.9$ minutes. There was no difference between the groups in mean PRA which remained within the normal range. Saralasin was infused incrementally in doses from 7.5 to $20 \mu \mathrm{m} \cdot \mathrm{kg}^{-1} \cdot \mathrm{min}^{-1}$ but failed to decrease $\overline{\mathrm{BP}}$ or SVR in any of the seven subjects. In fact, at low infusion rates $\left(7.5 \mu \mathrm{g} \cdot \mathrm{kg}^{-1} \cdot \mathrm{min}^{-1}\right)$, there was a temporary increase in $\overline{\mathrm{BP}}$ in all treated subjects (Figure 3). There was no correlation between PRA and $\overline{\mathrm{BP}}$ elevation during $\mathrm{CPB}$.

\section{Discussion}

The reported incidence of perioperative hypertension varies from 33 to 75 per cent in patients undergoing coronary artery revascularization ${ }^{6.7}$ but 
this may be affected by the choice of anaesthesia. Mcllvaine et $a^{8}{ }^{8}$ showed in a retrospective study that the use of high-dose morphine reduced the incidence of hypertension compared with halogenated volatile agents. High dose fentanyl anaesthesia, as an alternative to morphine, provides haemodynamic ${ }^{9}$ and hormonal ${ }^{10.11}$ stability during cardiac surgery. We have found previously that although high dose fentanyl does not eliminate hypertension, supplementary anaesthesia readily controls it. ${ }^{12}$ Furthermore, the incidence of hypertension can be correlated with plasma fentanyl concentration. ${ }^{13}$ In the present study patients were anaesthetized with high dose fentanyl and ventilated with 100 per cent oxygen. A non-pulsatile pump was used during CPB despite earlier reports that this might encourage the development of hypertension ${ }^{14}$ and stimulate renin release. ${ }^{15}$ These findings were not confirmed by Salerno et al. ${ }^{16}$ but their patients received greater beta blockade.

The mechanism involved in the production of hypertension may be different before, during and after $\mathrm{CPB}$ and may not be the same for all patients. In particular, renin secretion is reduced by sympathetic blockade ${ }^{17}$ and thus its role will be modified by propranalol therapy. Renin release is also reduced during hypothermia ${ }^{18}$ so that, during CPB, PRA will depend upon the degree of cooling. Ninety per cent of converting enzyme is found in the lungs ${ }^{19}$ which are isolated from the circulation during CPB so that conversion of angiotensin $I$ to angiotensin II is inhibited and the pressor effects of any renin released will not be seen. The renin secretion which may be influenced by hypovolemia and sodium balance was avoided in the present study by using crystalloid fluids to maintain filling pressures and to prime the pump. Despite these theoretical considerations, high PRA has been found during $\mathrm{CPB}^{4}$ and this has been blamed for postoperative hypertension. ${ }^{3}$

We observed hypertension in nine of 15 patients between induction of anaesthesia and the onset of $\mathrm{CPB}$ and in seven patients during CPB. Such hypertension has been associated with elevated plasma concentrations of several pressor hormones; catecholamines ${ }_{1}{ }^{1}$ vasopressin ${ }^{2}$ and renin-angiotensin. ${ }^{3}$ Of these three, the renin-angiotensin system is unique because angiotensin II inhibitors have been synthesized so that not only can plasma renin

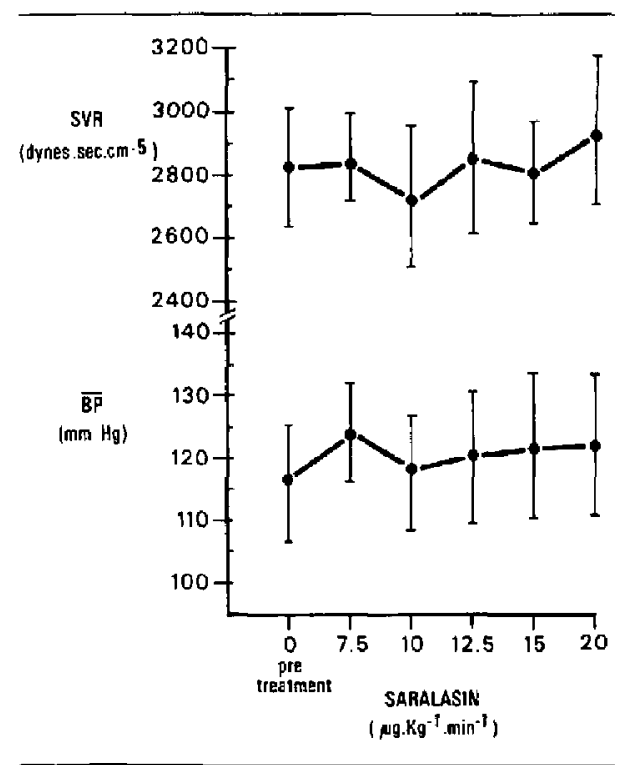

FIGURE 3 Haemodynamic responses to saralasin infusion during cardiopulmonary bypass.

activity be measured but also indices of the importance of angiotensin $\mathrm{H}$ can be obtained to determine its role in hypertension.

The mean PRA was not increased significantly in the groups of patients who became hypertensive either before or during CPB. Indeed, the mean values during $C P B$ tended to be lower in the hypertensive group. The infusion of saralasin in the CPB hypertensive group did not decrease either $\overrightarrow{\mathrm{BP}}$ or SVR in any patient. Indeed, a short-lasting agonist effect was seen at the lowest dose (Figure 3). Therefore, the absence of a hypotensive response to saralasin infused in doses sufficient to antagonize angiotensin $\mathrm{H}^{20}$ suggests that the reninagiotensin system does not have an aetiological role in CPB-hypertension. It is possible that it may be responsible for the hypertension which develops either before the start of, or after the conclusion of CPB. Landymore et al. ${ }^{18}$ showed that, in similar patients, propranalol therapy reduced PRA but had no influence on the incidence of hypertension in the immediate postoperative period but Niarchos et al. ${ }^{21}$ demonstrated that post-CPB hypertension responded to therapy with converting enzyme in- 
hibitor in eight of 13 patients. Thus it seems that the renin-angiotensin system is not the primary mediator of hypertension occurring during coronary artery surgery but that it may be responsible for postoperative hypertension in some patients.

The considerable increases in PRA, 4 to $15 \mathrm{ng}$. $\mathrm{ml}^{-1} \cdot \mathrm{hr}^{-1}$, reported by Bailey et al. ${ }^{4}$ were not seen in the present study. It is interesting that recent investigators ${ }^{22}$ have also failed to confirm that plasma vasopressin concentrations increase to the hyperphysiological, hypertensive range previously reported by Philbin et al. ${ }^{2}$ Thus it seems that $\mathrm{CPB}$ associated hypertension is not a consequence of activation of these pressor systems. Consequently, specific antagonist therapy is unlikely to be effective treatment. We conclude that the renin-angiotensin system is not the primary mediator of $\mathrm{CPB}$-associated hypertension, at least during fentanyl anaesthesia.

\section{References}

1 Turton MB, Matthews HR. Catecholamines and peripheral vasoconstriction after open heart surgery. Clin Chim Acta 1974; 50: 419-23.

2 Philbin DM, Levine FH, Emerson CW, Coggins CH. Buckley $M J$, Austen WG. Plasma vasopressin levels and urinary flow during cardiopulmonary bypass in patients with valvular heart disease. J Thorac Cardiovasc Surg 1979; 78: 779-83.

3 Taylor KM, Morton $I J$, Brown $J$, Bain WH, Caves $P K$. Hypertension and the renin-angiotensin system following open heart surgery. J Thorac Cardiovasc Surg 1977; 74: 840-5.

4 Bailey DR, Miller RD, Kaplan JA, Rogers PW. The renin-angiotensin-aldosterone system during cardiac surgery with morphine-nitrous oxide anesthesia. Anesthesiology 1975; 42: 538-44.

5 Haber E, Koerner T, Page LE, Kliman B, Pernode $A$. Application of radioimmunoassay for angioten$\sin$ I to the physiologic measurements of plasma renin activity in nomal human subjects. J Clin Endocrinol Metab 1969; 29: 1349-55.

6 Estafanous GF, Tarazi RC, Viljoen JF, EI Tawil $M Y$. Systemic hypertension following myocardial revascularization. Am Heart J 1973; 85: $732-8$.

7 Hoar PF, Hickey RF, Ullyot DJ. Systemic hypertension following myocardial revascularization. A method of treatment using epidural anaesthesia. J Thorac Cardiovasc Surg 1976; $71: 859-64$.
8 Mcllvaine W, Boulanger M, Maille JG, Paiement $B$. Taillefer J, Sahab $P$. Hypertension following coronary artery bypass graft. Can Anaesth Soc J 1982; 29: 212-7.

9 Lunn JK, Stanley TH, Eisele J, Webstar L. Woodward $A$. High dose fentanyl anaesthesia for coronary artery surgery: Plasma fentanyl concentrations and influences of nitrous oxide on cardiovascular responses. Anesth Analg 1979: 58: 390-5.

10 Stantley TH, Philbin DM, Coggins CH. Fentanyloxygen anaesthesia for coronary artery surgery: cardiovascular and antidiuretic hormone responses. Can Andesth So: J 1979; 26: 168-72.

11 Kono K, Philbin DM, Coggins CH et al. Renal function and stress response during halothane or fentanyl anaesthesia. Anesth Analg 1981;60: 552-6.

12 Sprigge JS, Wynands JE, Whalley DG et at. Fentanyl infusion anaesthesia for aortocoronary bypass surgery: plasma levels and hemodynamic response. Anesth Analg 1982; 61: 972-8.

13 Wynands JE, Townsend GE, Wong $P$, Whalley $D G$, Srikant $C B$, Patel YC. Blood pressure tesponse and plasma fentanyl concentrations during high- and very high-dose fentanyl anaesthesia for coronary artery surgery. Ancsth Analg 1983; 62: 661-5.

14 Landymore RW, Murpiny DA, Kinley CE et al. Does pulsatile flow influence the incidence of pastoperative hypertension? Ann Thorac Surg 1978; 28: 261-8.

15 Taylor KM, Bain WH, Maxted KJ, Hutton MH, McNab WY, Caves PK. Comparative studies of pulsatile and non-pulsatile flow during cardiopulmonary bypass. J Thorac Cardiovasc Surg 1978; 75: 569-84.

16 Salerno TA, Henderson M, Keith FM, Charrette EJP. Hypertension after coronary operation: can it be prevented by pulsatile perfusion? J Thorac Candiovasc Surg 1981; 81; 396-9.

17 Buhler FR, Laragh JH, Baer L et al. Propranalol inhibition of renin secretion: a specific approach to diagnosis and treatment of renin-dependent hypertension. N Engl J Med 1972; 287; 1209-14.

18 Landymore $R W$, Murphy $D A$, Kinley E, Parrott J, Sai O, Quirbi AA. Suppression of renin production in patients undergoing coronary artery bypass. Ann Thorac Surg 1980; 30: 558-63. 
$19 \mathrm{Ng} N F K$, Vane JR. Conversion of angiotensin I to angiotensin II. Nature 1967; 216: 762-6.

20 Brunner HR, Laragh JH. Saralasin in human hypertension: the early experience. Kidney lint 1979; 15: $\mathrm{S} 36-43$.

21 Niarchos AP, Roberts AJ, Case DB, Gay WA Laragh $J H$. Hemodynamic characteristics of bypertension after coronary artery surgery and effects of the converting enzyme inhibitor. Am J Cardiol 1979; 43: 586-93.

22 Crone LA, Wilson N, Hgsee J, Turnbull KW, Leighton $K$. Haenodynamic and plasma vasopressin responses with high-dose fentanyl anaesthesia during aorto-coronary bypass operations. Can Anaesth Soc J 1982; 29: 525-32.

\section{Résumé}

Nous avons étudié la participation du système rénineangiotensine dans l'étiologie de l'hypertension périopératoire chez 15 patients normotensifs soumis à une chirurgie coronaire sous anesthésie au fentanyl. Les mesures de l'activité de la rénine plasmarique ont élé effectués a intervalles avant et durant la circulation exracorporelle (CEC). En plus, on a utilisé la saralasine, un bloqueur de l'angiotensine II pour tenter de traiter l'hypertension durant la CEC.

Neuf patients ont présenté de l'hypertension laugmentation des pressions systémiques de plus de 20 pour cent) avant la CEC: l'activité de la rénine plasmatique était plus élevée dans ce groupe que chez les patients normotendus cependant elle demeurait dans les limites de la normale.

Durant la CEC, sept malades ont présenté de l' hypertension (pression moyenne plus grande que $100 \mathrm{mmHg}$ à $1.8 \mathrm{l} \cdot \mathrm{m}^{-2}$ de dêbit), mais cette hypertension n'était pas associée avec une augmentation d'activité de la rénine plasmatique et elle n' a pas répondu d la saralasine d̀ des doses qu' on a montées jusqu'a $20 \mu \mathrm{g} \cdot \mathrm{kg}^{-1}-\mathrm{min}^{-1}$. On a conclu que l' hypertension survenani au cours de la CEC n'est pas attribuable d̀ l'activation du système rénineangiotensine. 